\title{
IMPACT OF ORGANIC AND CONVENTIONAL FARMING PRACTICES ON SOIL QUALITY: A GLOBAL REVIEW
}

\author{
SHEORAN, H. S. ${ }^{1 *}-$ KAKAR, R. ${ }^{2}-$ KUMAR, N. $^{3}-$ SEEMA $^{1}$ \\ ${ }^{I}$ Department of Soil Science, CCS Haryana Agricultural University \\ Hisar-125004, Haryana, India \\ ${ }^{2}$ Haryana Space Applications Centre, CCS HAU Campus, Hisar-125004, Haryana, India \\ ${ }^{3}$ Department of Agronomy, CCS Haryana Agricultural University \\ Hisar-125004, Haryana, India \\ *Corresponding author \\ e-mail: sheoranhardeep2008@gmail.com
}

(Received $10^{\text {th }}$ Jul 2018; accepted 20 $0^{\text {th }}$ Dec 2018)

\begin{abstract}
As world population grows, the demand for food production increases ultimately creating a huge pressure on our shrinking natural resources. With this increased demand for food researches have realized that conventional farming would neither be able to increase productivity nor would be able to improve the soil quality and there is a need for an alternative farming practice to conserve our environment while sustaining the natural resources. Among the alternative practices, organic farming, which is very popular, aims at reducing the use of synthetic fertilizers and pesticides in order to improve production and ecosystem health. The aim of our paper is to compare the long term effects of conventional and the alternative organic farming practices on soil quality and crop productivity as they are considered to be two major indices that measure agricultural sustainability on long term basis. Therefore, many studies around the world are evaluating the organic farming practices as an alternative was found to be superior in their physical, chemical and biological properties than their conventional counterparts. In addition, the studies showed that the organic farming practices are economically viable in the long term for both crop productivity and environmental sustainability.
\end{abstract}

Keywords: management practices, soil properties, microbial communities and soil quality

\section{Introduction}

"Soil: A living and life-giving natural resource, dynamic natural body on the surface of the earth in which plants grow, composed of mineral and organic materials and living forms." N. C. Brady

The world's populations currently is increasing at an exponential rate and as the demand for food production increases, tremendous pressure and demands are going to be positioned on our natural resources like soil. Conventional methods of farming largely include the use of high dose of synthetic fertilizers and agrochemicals with heavy reliance on tillage practices which will continue to be the customary method of fabrication and the penalty will be reflected in terms of diminished soil quality, affecting the soil's ability of crop production (Gomiero et al., 2011). In contrast, organic farming attempts to mimic or follow natural processes that tend to improve soil and plant health while preserving soil and water resources (Gomiero et al., 2011). These intensive farming practices have resulted in a decline in soil organic matter affecting the soil physical, chemical and biological properties. The declining soil quality due to reduced level of organic matter is imposing a serious threat to sustainability of present agricultural systems which are completely relying on agro-chemicals and high energy 
inputs. These inputs have an enormous deleterious impact on soil and water, causing degradation in form of erosion, alkalinity, salinity, acidification, water logging, macro and micronutrients deficiencies that ultimately affect soil quality and crop productivity (Lopes et al., 2011). In addition, excessive use of fertilizers and pesticides causes the accumulation of toxic elements that are resistant to degradation in the soil. It is well established that overall, conventional farming leads to degradation of soils, and certainly going to create problems in achieving the target of sustainability in terms of agricultural production. These challenges questioning to sustainability are going to be accelerated by affecting natural weather phenomenon such as longer periods of drought, which may be attributed to climate change (Montgomery, 2007a). Further, leaching losses of nitrate cause eutrophication of surface waters and contamination of groundwater. Moreover, when soil applied pesticides fails to reach the target, they affect adjacent ecosystems through leaching or aerial drift affecting the diversity and abundance of non targeted microorganisms causing negative effects on ecosystem processes and trophic interactions (Pimentel and Edwards, 1982). There is growing realization among agricultural scientists that though the conventional farming practices have led to achieve the target of self sufficiency (increased food production) but it was at the cost of quality of food, deterioration in environment and degradation of natural resources. Therefore, there is a growing concern about the environmental, economic and social effects of chemical-dependent conventional farming system that have led the scientific community to seek alternative systems that may make agriculture more sustainable and profitable.

Though, agricultural practices are of numerous types and based on the farming techniques they can be generalized as organic, sustainable or conventional. Organic farming aims to thrive plenty of crops, without inclusion of synthetic fertilizers or growth regulators, while sustaining soil quality. This can be called as a traditional method of farming that completely relies on ecosystem services, maintains the integrity of the soils while attaining potential yields (Willer and Lernoud, 2013). Organic farming relies on on-farm techniques of crop rotation, use of organic manures such as vermicompost, farmyard manure (FYM) etc., however, noticeable changes in soil properties could occur only after several years of continuous adoption of these practices. The real picture of overall sustainability with organic farming practices, however, continues to face many challenges. For instance, the Rodale Institute Farming System trial is a well-received study that started in 1981 and has continued to the present (Rothamsted Research, 2005). The experimental trials represent a holistic comparison of the effects of the conventional and organic farming practices soil health, and the study also analyzed the crop yields, economic and energy inputs, and human health and clearly indicated that organic farming was found to be superior in every aspect over conventional system of management (Fig. 1).

Due to the many different factors determining crop productivity and soil health, there is a need for much more extensive research on the subject. Therefore, goal of writing this review paper was to use reliable, long-term research that made specific assessments of the two generalized types of farming and then compare the results.

\section{Review of work done}

The pertinent literature on the evaluation of soil quality under different land management practices has been reviewed under the following heads: 
Soil physical properties

Bulk density

Infiltration rate

Aggregate size distribution

Moisture retention characteristic

Soil chemical properties

$\mathrm{pH}, \mathrm{EC}, \mathrm{CaCO}_{3}$

Soil organic carbon and its fractions

Available N, P, K and micronutrients

Soil biological properties

Microbial biomass carbon

Microbial population and enzymatic activities
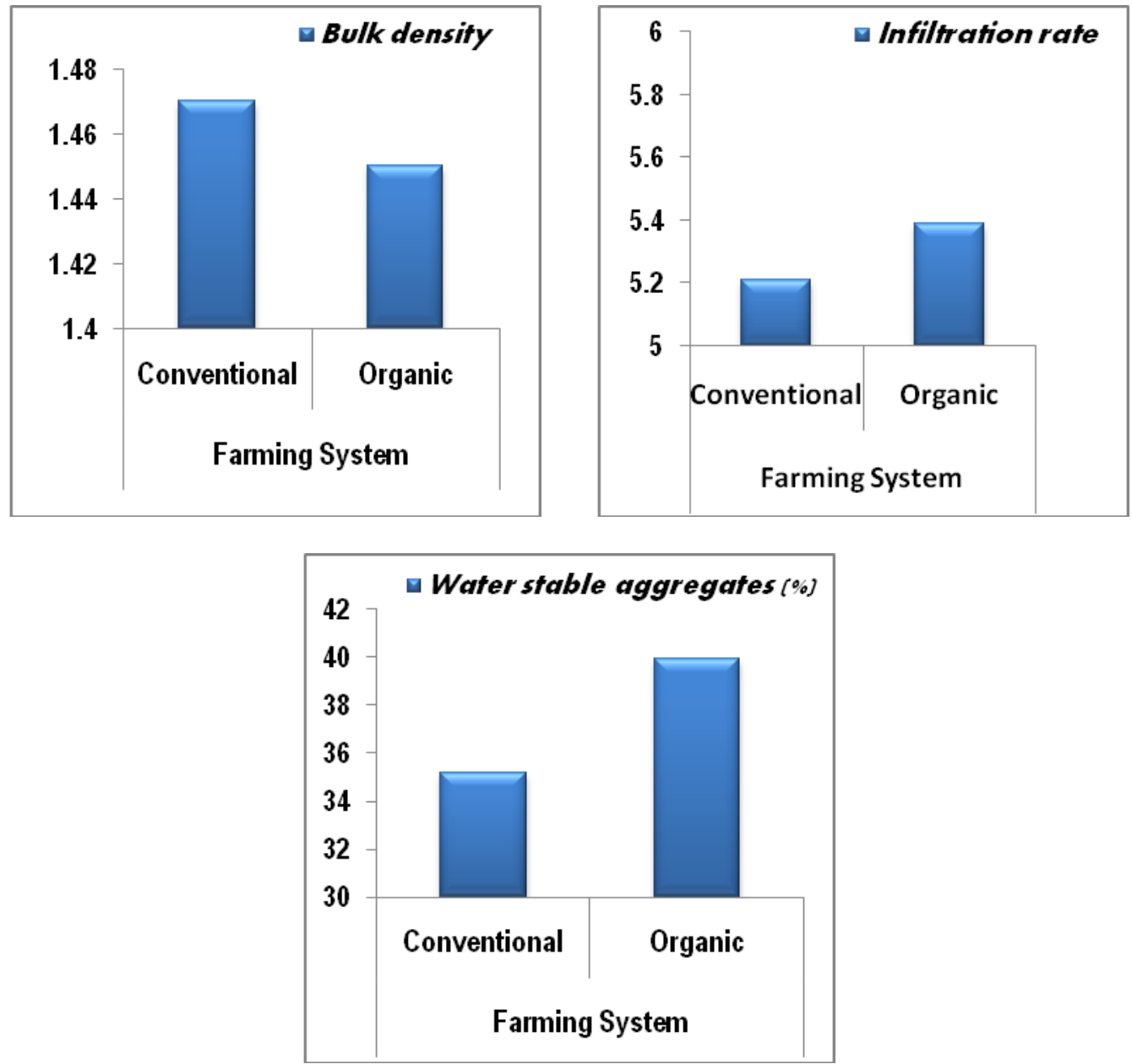

Figure 1. The bulk density, infiltration rate and WSA of soils under organic and conventional farming system (Sheoran, 2018)

\section{Soil physical properties}

\section{Bulk density}

The literature available on the effect of organic farming on soil bulk density is controversial. Some of the long-term trails have shown no significant difference in bulk 
density (Rothamsted Research, 2005) between organically and conventionally managed soils while other have reported reduction in bulk density (Shepherd et al., 2002; Chen et al., 2011; Hati and Bandyoopadhay, 2011). The continuous application of organic material reduces compaction, bulk density and penetration resistance (Chen et al., 2011) and provides more favorable physical properties than in the conventional fertilized systems in surface soil. Quist et al. (2006) studied the influence of alternative and conventional management practices on soil physical and hydraulic properties and reported that bulk density in the surface layer was 3\% lower under alternative management practices $\left(1.39 \mathrm{Mg} \mathrm{m}^{-3}\right)$ than under conventional practices $\left(1.43 \mathrm{Mg} \mathrm{m}^{-3}\right)$. Sihi et al. (2017) studied soil health in organic versus conventional farming of basmati rice (Oryza sativa) in North India and reported lower bulk density $\left(1.26\right.$ and $1.31 \mathrm{Mg} \mathrm{m}^{-}$ 3 in organic and conventional farming, respectively) under organic farming. Similar results were also reported by Suja et al. (2017) in Taro (Colocasia esculenta (L.) Schott).

\section{Infiltration rate}

The land-use pattern and the land-management i.e., conventional and organic farming, both have different impacts on the infiltration capacity and water storage of the soils. Continuous application of organic matter helps in improving soil structure and subsequently alteration in pore size distribution. Levick (1992) found significantly higher water infiltration, porosity, organic carbon and soil respiration, and lower bulk density and penetration resistance in bio-dynamically farmed than the conventionally farmed soils. High inputs of fertilizers and the use of heavy machinery leads to soil compaction and loss of soil biological activity while organic farming system produces a sustainable soil structure with high biological activity which enhances water infiltration and soil water-holding capacity (Poudel et al., 2001; Quist et al., 2006; Jenkins et al., 2011; Williams et al., 2017). Furthermore, the biological activities supported by organic farming have plenty of bio-pores which in turn enhance water infiltration rates into the soil (Schnug and Haneklaus, 2002). Organic farming system is more useful for earthworm populations as compared to the conventional system resulting into greater number and biomass of earthworms which produce more "biopores" in the soil, and hence creates higher infiltration capacity (Schnug et al., 2004). Fueki et al. (2012) carried out a study to clarify the differences in physical aspects (water permeability and macropores) between organically and conventionally managed soils and reported that the infiltration rate was 6-10 times higher in organic soils than in conventionally managed soils, owing to larger macropores in organic management. Similar results were published by Das et al. (2015) for north-east India reporting the infiltration rate of $3.18 \mathrm{~cm} \mathrm{hr}^{-1}$ in the conventional to $17.69 \mathrm{~cm} \mathrm{hr}^{-1}$ in the organic fields.

\section{Aggregate size distribution}

The effect of organic farming on aggregate stability in apple (Malus domestica) orchard was assessed by Chung (2007) in relation to conventional farming and results revealed that organic farming produced greater aggregation in $>2 \mathrm{~mm}$ size and increased aggregate stability. Zhao et al. (2017) studied the stability and size distribution of soil aggregates under different land uses and measured as mean weight diameter, the percentage of water-stable aggregate and the percentage of each size fraction. The study suggested that land use affected the stability and size distribution of 
soil aggregates through the integration of soil organic matter and types of land use. Greater organic matter buildup in organic fields is critical to increase soil aggregate stability (Papadopoulos et al., 2006; Thuries et al., 2001; Sihi et al., 2017). In a study in Switzerland analyzing both biodynamic and organic plots compared to conventional (Fließbach et al., 2007) it was found that significantly higher aggregate stability and water infiltration rates occurs within the organically managed fields, however, a number of European studies found no difference between conventional and organic (Petersen et al., 1997). Higher aggregate stability was measured in organic than in conventional farming systems (Siegrist et al., 1998). Soil aggregate stability was strongly correlated with earthworm activity which was found to be higher under organic than under conventional management (Mader et al., 2002). Organic farming with animal manure has been shown to increase water-stable aggregates compared with conventional farming with inorganic fertilizers (Pulleman et al., 2004).

\section{Moisture retention characteristic}

Water retention and transport capacity of a soil is greatly influenced by addition of organic matter and tillage practices (Franzluebbers et al., 2000; Shukla et al., 2003). Organic matter addition and decomposition added organic matter leads to alteration of pore size distribution which is directly related to water retention, storage, and transport within the soil. Although the volume of transmission pores has been reported to be decreased with time under organic farming primarily at 10-20 and 20-30 cm depths but there was only little variation in other physical properties related to soil structure (Ikemura et al., 2008) invalidating the hypothesis that manure application would show better soil structure in organic than conventional farming. Krol et al. (2013) compared the effect of organic and conventional management systems on various soil properties including total porosity, water and ethanol sorptivity, repellency index, and tensile strength of soil aggregates and found that infiltration and sorptivity of water in aggregates were greater under organic than conventional management practices. There were significant differences in soil bulk density, porosity and water content among soils from organic and conventional management systems (Liu et al., 2007). The physical properties such as saturated and unsaturated hydraulic conductivity, water retention capacity, bulk density, total porosity, pore size distribution, soil resistance to penetration, aggregation, and aggregate stability were improved in plots amended with sewage (Aggelides and Londra, 2000). Similarly, Williams et al. (2017) investigated the long term impacts of organic management on soil aggregate stability, bulk density, water infiltration, saturated hydraulic conductivity, and soil water retention characteristics. Results indicated that organically managed soils have more water-stable aggregates, greater ability to absorb irrigation water, and less compactable than conventionally farmed soils. Mean weight diameter of water-stable soil aggregates increased by fifty percent with the organic management. Sunita (2015) reported that plant available water content and water retention capacity showed increased values in organic soil, compared with conventionally farmed soil. The organic farming based on animal or green manure improved physical properties of soils by lowering its bulk density, increasing water-holding capacity and improves infiltration rates (Lee et al., 2006). The higher porosity at the macroscale in soil under conventional management was due to fewer larger pores while meso and micro scale porosity was found to be greater under organic management. Organically managed soils typically provided spatially well distributed pores of all sizes and of greater roughness compared to those 
under conventional management. Malik et al. (2014) attempted to find difference in physical properties of soils under conventional and organic management. Data indicated that water retention was significantly higher $(59.43 \%)$ at surface depth and $(60.30 \%)$ value for subsurface depth under organic treatment. However, many benefits arise from increased organic additions to the soil (a practice common in organic agriculture) such as improvements in fertility and water holding capacity (Bhogal et al., 2009; Wortman et al., 2011), increase in soil resilience by reducing susceptibility to erosion, retaining soil moisture levels (water retention), and increasing the overall capability of the soil to maintain production (Shepherd et al., 2003). In the study conducted by Zeiger and Fohrer (2009), soil moisture content in the organic farm was relatively higher in comparison to conventional farm. Organic agriculture management promotes the maintenance of higher soil organic matter (Lampkin et al., 2011) and higher microbial biomass, larger fractions of mineralizable $\mathrm{C}$ and $\mathrm{N}$, and greater microbial $\mathrm{C}$ and improvement inter aggregate stability (Reganold et al., 2010). Thus the physical properties of the soil can be used as indicators for making assessment of soil-quality and assessing sustainability of organic farming systems.

Adoption of organic farming was found to significantly influence the physical properties of soils (Fig. 1) and it can be concluded that conversion of land from conventional to organic farming system in long run have the potential to improve the soil physical properties and provide a prominent strategy for enhancing soil physical health while achieving the target of agricultural sustainability.

\section{Soil chemical properties}

\section{pH, EC and $\mathrm{CaCO}_{3}$}

Organic farming system has been reported to increase the $\mathrm{pH}$ (Ikemura et al., 2008; Chin et al., 2010; Otero et al., 2010; Mendoza et al., 2011; Lee et al., 2014; Suja et al., 2017) and electrical conductivity (EC) (Ikemura et al., 2008; Mendoza et al., 2011) of acid soils and improve the availability of nutrients without exhausting the soil (Otero et al., 2010). The EC values mostly increased with increasing amount of time under organic farming. A comparative study of organic and conventional farming system at three different slope sections (Chong et al., 2008) showed that the soil $\mathrm{pH}$ increased in organics as compared to conventional farming plots. In his case study on chemical properties, microbial biomass, and activity between soils of organic and conventional horticultural systems under open field management. Ge et al. (2011) however observed highest $\mathrm{pH}$ (8.38) in conventionally managed plots followed by organic management (8.03). Herencia et al. (2007) and Abu-Zahra and Tahboub (2008), however reported no difference in soil $\mathrm{pH}, \mathrm{EC}$ and calcium carbonate among plots managed organically as well as conventionally. On the other hand, Sihi et al. (2017) reported the enhanced availability of nutrients in organic fields due to favorable soil $\mathrm{pH}$. Soil $\mathrm{pH}$ was 0.5 unit lower and EC was $26 \%$ lower in organic fields as compared to conventional fields due to excessive salts accumulations from chemical fertilizer usage (Velmourougane, 2016).

\section{Soil organic carbon and its fractions}

A large volume of literature is available which supports that long term organic farming increases the soil organic carbon (SOC) quite significantly over the conventional system under different crops/cropping systems (Liebig and Doran, 1999; 
Marriott and Wander, 2006; Leifeld et al., 2009; Aher et al., 2015; Jadhav et al., 2016; Gajda et al., 2016; Maharjan et al., 2017) including integrated use of organic and fertilizers (Aher et al., 2015). The magnitude of increase in organic carbon was, however, observed to be higher in fields receiving farmyard manure (FYM), neem cake and vermicompost (Jadhav et al., 2016). It is largely reported that organic farming increases the content of particulate organic matter fraction in total organic matter.

Different fractions of soil organic carbon have been reported to respond differentially to land use and management (Degryze et al., 2004; Malhi et al., 2011; Benbi et al., 2012). Benbi et al. (2012, 2016) found significantly higher concentration of particulate organic carbon (POC) in organically amended plots under rice wheat system than the ones receiving fertilizer nitrogen only. The POC pools were lower, however, in subsurface than the surface soil. Addition of farmyard manure (FYM) alone or in combination with rice straw enlarged the light fraction organic carbon (LFOC) pool by 263 and 383\%, and heavy fraction organic carbon (HFOC) pool by 62 and 127\%, respectively, with insignificant effect on mineral associated organic carbon (MOC). Marriott and Wander (2006) investigated the veracity of common perceptions about soil organic matter quantity in organically and conventionally managed soils by evaluating the relative responsiveness to organic management of particulate organic matter (POM). The results revealed that organic management enriched the soil particulate organic carbon (POMC) by 30 to $40 \%$ relative to the conventional and this level of enrichment was two to four times greater than that in any other fraction. Similar results were earlier reported by Fortuna et al. (2003). Wander and Traina (1996) reported that organic systems had significantly higher quantities of carbon in its light fraction and heavy fraction than the conventionally managed soils.

In many studies, the SOC stocks under organic and conventional systems of farming have also been compared (Canqui et al., 2013; Leifeld and Fuhrer, 2010). Canqui et al. (2013) found the organic farming to increase SOC stocks, aggregate associated SOC and POC concentrations but only in surface soil depth. The SOC stock under organic cattle manure system was $19 \%$ greater than under conventional farming $\left(33.1 \mathrm{Mg} \mathrm{ha}^{-1}\right)$. Leifeld and Fuhrer (2010) reported that higher SOC accumulation in organic systems is mainly due to the higher application of organic fertilizer compared with most conventional farming systems. Converting cropland to organic production may provide significant GHG reduction opportunities over the next few decades by increasing the soil organic carbon stocks (Kumar, 2012). Mohamad et al. (2016) reported that manure was the primary contributor to increased SOC in the organic system, resulting in a higher efficiency of carbon sequestration in the soil following the addition of soil organic matter. The contribution of the manure to increased SOC compensated for the higher carbon emission from the organic system, resulting in higher negative net carbon flux in the organic versus the conventional system.

\section{Available N, P, K and micronutrients}

Various studies have been reported that organic farming have potential to increase the level of total nitrogen, nitrate and available phosphorus in soil and prevent nutrients leaching (Hansen et al., 2001; Diepeningen et al., 2006) due to manure inputs and the use of cover crops. Herencia et al. (2007) conducted a study over a period of nine years in Spain and found that organic farming management resulted in higher soil organic carbon, $\mathrm{N}$ and available $\mathrm{P}, \mathrm{K}, \mathrm{Fe}$ and $\mathrm{Zn}$. The available $\mathrm{Mn}$ and especially $\mathrm{Cu}$ values did not show significant differences. Liebig and Doran (1999) presented significantly higher 
total soil nitrogen in the organic farm than in the conventional farm. Studies that compare organic and conventional farming practices in soils show higher organic matter and macronutrient contents under organic farming (Edmeades, 2003). Monokrousos et al. (2006) found significantly higher extractable soil phosphorus content in organic asparagus (Asparagus officinalis) field in comparison to conventional field. In contrast, Romanya and Rovira (2009) indicated significantly higher soil phosphorus content in conventional farm in comparison to organic farm. Andrist et al. (2007) compared soil potassium content between conventional farm and organic farm from 1987 to 2004 in Sweden and found non-significant difference. Lotter (2003) indicated that organic farm can either have significantly higher or no significant difference in soil potassium content than in conventional farm. A comparative study of commercial organic and conventional vegetable farming systems was carried out by Shrestha (2014) to find out impact of different farming systems on soil properties. Results showed that total soil nitrogen and available soil nitrogen content were significantly higher in comparison to the organic farm. Available soil potassium content was significantly higher in the organically managed soil than in the conventionally managed soil. Sudhakaran et al. (2013) found that soils from organic farms had improved soil chemical parameters (total elements and available nutrients) and higher level of total $\mathrm{N}, \mathrm{P}, \mathrm{K}, \mathrm{Ca}, \mathrm{Mg}, \mathrm{Fe}, \mathrm{Cu}, \mathrm{OC}$, $\mathrm{NH}_{4}-\mathrm{N}, \mathrm{NO}_{3}-\mathrm{N}, \mathrm{SO}_{4}-\mathrm{S}$ and soluble sodium. A short term organic farming resulted in higher SOC, $\mathrm{N}$ and available $\mathrm{P}, \mathrm{K}, \mathrm{Fe}$ and $\mathrm{Zn}$ but not available $\mathrm{Mn}$ and $\mathrm{Cu}$ in soil. Smitha et al. (2015) carried out a study on soil and plant nutrient status as influenced by organic farming in Long pepper (Piper longum) and reported that the application of organic manures has a significant impact on plant and soil nutrient and increased the levels of available NPK and microbial population in the soil after three years of cropping. Sihi et al. (2012) and Askegaard and Eriksen (2007) observed a higher available (potentially mineralizable) $\mathrm{N}$ concentration in organic systems resulting from the substantial input of nitrogen from different organic manures which mainly include green manures and legumes that release nitrogen simultaneously with the plant demand and reduce nitrogen loss through leaching and volatilization. Likewise, organic farming with legumes and organic amendments (i.e., manure) often increases nutrient concentrations and biological activity (Pelosi et al., 2015). For example, in eastern Nebraska, organic matter, $\mathrm{Ca}, \mathrm{K}, \mathrm{Mg}$, and $\mathrm{Zn}$ concentrations increased with organic farming (Wortman et al., 2011). Uddin et al. (2016) studied the impact of organic and conventional practices on physic-chemical properties and reported the significant increase in the health properties including $\mathrm{pH}$, available organic matter, nitrogen, and $\mathrm{P}$, $\mathrm{K}, \mathrm{Ca}$, and $\mathrm{S}$ increased significantly in the compost-amended soils compared to the conventional practices. Similarly, Aher et al. (2015) observed that available nitrogen (125 mg kg-1) and $\mathrm{P}\left(49.7 \mathrm{mg} \mathrm{kg}^{-1}\right)$ were significantly higher in the plot managed organically while available $\mathrm{K}\left(320.1 \mathrm{mg} \mathrm{kg}^{-1}\right)$ was not significant with respect to chemical and integrated practices.

The long-term effects of organic versus conventional farming on soil properties were reviewed and from the literature it can be revealed that organic farming can be considered as an eco-friendly as compared to conventional farming in maintaining soil health. Shifting from conventional to organic farming enhanced the soil organic carbon and its fractions and overall carbon stocks in soils were observed to be higher in organic soils over the conventionally managed soils with higher available plant nutrients (Figure 2). 

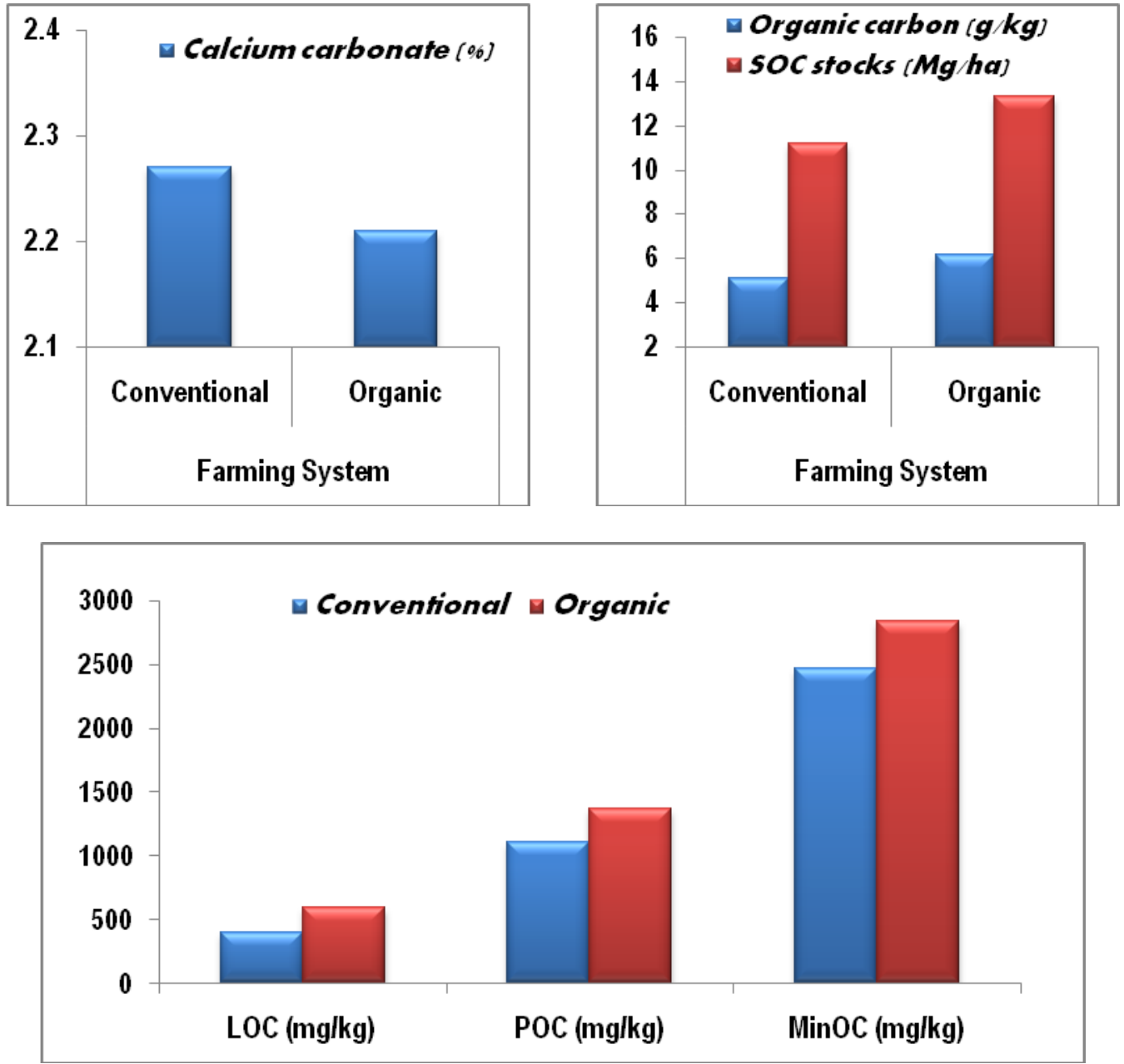

Figure 2. Some chemical properties of soils under organic and conventional farming system (Sheoran, 2018)

\section{Soil biological properties}

\section{Microbial biomass carbon}

Microbial biomass has been found to be higher in organically managed soils than in conventionally managed (Schjonning et al., 2002; Crecchio et al., 2004; Melero, 2006; Araujo et al., 2009; Amaral et al., 2011) due to the permanent input of organic residues with high $\mathrm{C} / \mathrm{N}$ ratio. Liu et al. (2007) reported that soils under organic farming had higher microbial biomass carbon and nitrogen, and net mineralizable N. In addition, soil microbial respiration was higher in soils from organic than conventional farms indicating higher microbial activity and populations of Fungi and thermophiles (Thermophilies detected in this study were mainly Actinomycetes; which are indigenous soil bacteria which can be responsible for both the degradation of plant debris and inhibition of soil borne diseases) were also significantly higher in soils from organic than conventional managed fields. Similarly, Okur et al. (2009) reported that SOC and soil microbial biomass $\mathrm{C}$, and protease, urease, alkaline phosphatase, and dehydrogenase activity were significantly higher in the organic farming system than the conventional system. 
Stark (2008) evaluated the effect of two organic and conventionally managed sites on soil microbial biomass. The organic site has been managed under a low input six year rotation (Lolium perenne, Medicago sativa and Trifolium repens) and organic fertilization with compost or manures. The results showed positive effect of the management on soil microbial biomass. The influence of different farming systems on microbial community were analyzed using samples from long term field experiment in Switzerland by Esperschutz (2007). The experiment comprised organic and conventional farming systems as well as an unfertilized as control. They observed higher concentrations of phospholipids fatty acids in organic system, indicating a clear influence of the system on microbial biomass. Gajda et al. (2016) found higher activity of microorganisms as measured by fluorescein diacetate hydrolysis under organic farming. Maharjan et al. (2017) studied the effect of land use and management practices on microbial biomass and enzyme activities in subtropical top and sub-soils and found that organic $\mathrm{C}$ and $\mathrm{N}$ contents as well as microbial biomass were significantly higher in the organic farming topsoil as compared to conventional farming.

\section{Microbial population and enzymatic activities}

Benbi et al. (2016) studied the differences in soil organic carbon fractions and biological activity between organic and conventionally managed rice-wheat fields. Under both the systems of management, the highest population was of culturable Bacteria followed by Actinomycetes and the least in case of Fungi in terms of their population which is represented in numbers. The population of culturable Bacteria, Fungi and Actinomycetes were significantly higher under organic than conventional system of farming. Lopes et al. (2011) ascertained that both organically and conventionally farmed soils show temporal variations in the functional but not in the bacterial community structure. Use of an organic fertilizer instead of a synthetic fertilizer is reported to reduce groundwater contamination, improve microbial activity, recycle dairy/poultry wastes and improve soil physical and chemical properties (Pang and Letey, 2000; Poudel et al., 2002). In recent years, multiple studies comparing conventional and organic agriculture have reported differences in soil properties, higher microbial activity and diversity in organically managed soils, or distinct microbial profiles between the two systems (Wu et al., 2008). Bobulska et al. (2015) reported large differences between the organic and conventional sites in terms of microbiological properties, which are sensitive soil indicators of changes occurred under different farming systems. The study confirmed the positive influence and higher microbial activity indices of ecological farming (36\% higher enzymatic activity, 65\% higher soil respiration content, $60 \%$ higher soil microbial biomass carbon content) compared to conventional farming system. Moeskops et al. (2010) compared the effect of organic and conventional farming practices on soil microbial dynamics in West Java, Indonesia and concluded that based on the amounts of marker fatty acids, all microbial groups considered (Actinomycetes, Bacteria, AMF and Fungi) were significantly higher in organically managed soil than in soil from conventional farms $(\mathrm{P}<0.01$, except for Fungi: $\mathrm{P}<0.05)$. Babu et al. (2014) conducted a field study to determine the vertical distribution of carbon, nitrogen and other soil properties in four representative soil profiles, one each from <3 years, 3-6 years and $>6$ years of organic farming practice and one profile representing conventional farming system. Results showed that the enzymatic activities (dehydrogenase and phosphatase) were consistently higher in the surface layer (Ap horizon) in all the four representative profiles studied and the activity 
of dehydrogenase and phosphatase of soil increased significantly in the fields subjected to organic farming for three specified time periods irrespective of cropping systems evaluated over conventional farming, with maximum activity being in the profile where organic farming has been practiced for over six years. Ge et al. (2011) carried out a comparative study of organic and conventional arable farming systems and reported the extreme differences between organic and conventional management practices and were reflected in strong differences in microbial biomass and enzyme activities. Velmourougane in 2016 evaluated the long-term impacts of organic and conventional methods of coffee farming on soil physical, chemical, biological, and microbial diversity. Organic system was found to have higher macrofauna (31.4\%), microbial population $(34 \%)$, and microbial diversity indices compared to conventional system. Sudhakaran et al. (2013) investigated the effects of different farm management practices (conventional and organic) on soil biochemical and microbial populations and reported that microbial population (Bacteria, Fungi, Actinomycetes, Beijerinckia, Azotobacter, Bacteria, Rhizobium, bacillus (Bacillus is a genus of gram-positive, rod-shaped bacteria and a member of the phylum Firmicutes. Bacillus species can be obligate aerobes (oxygen depending), or facultative anaerobes (having the ability to be aerobic or anaerobic) and phosphobacteria) were higher in soils from organic farming than sustainable and conventional farms. Carine et al. (2009) also reported that the soil enzyme activities and microbial population are higher in organically managed farm compared to the counterpart's conventional farms. Uddin et al. (2016) studied the impact of organic and conventional practices on physic-chemical properties, behavior and persistence of plant growth promoting microorganisms including Rhizobium, Azotobacter, phosphate solubilizing Bacteria etc. and reported that population of beneficial soil microbes and health properties including $\mathrm{pH}$, nitrogen content, organic matter, phosphorus, $\mathrm{K}, \mathrm{Ca}$, and $\mathrm{S}$, increased significantly in the compost-amended soils compared to the conventional practices. Soil enzymatic activities, organic carbon and microbial population were assessed by Jadhav et al. (2016) and reported that higher population of Actinomycetes $\left(118 \times 10^{5} \mathrm{~g}^{-1}\right.$ soil $)$, fungal $\left(141 \times 10^{4} \mathrm{~g}^{-1}\right.$ soil $)$ and Bacteria $\left(159 \times 10^{6} \mathrm{~g}^{-1}\right.$ soil $)$ were observed with the application of organic materials. Moreover, dehydrogenase and phospharase activities were increased also increased significantly. The incorporation of cover crops or other organic soil amendments significantly improve soil microbial properties under potato (Solanum tuberosum) (Ochiai et al., 2008). In an apple orchard, biological soil properties were improved in the organic compared to the conventional management, however, there were significant differences in soil properties between the conventional and organic farming practices (Glover et al., 2000). Most research suggests that organic farming practices have a positive, stimulating influence on the soil microbes by enhancing diversity and improving soil functions like nutrient cycling and antagonistic potential and it was clearly established that soil quality was higher in soils under organic farming (Girvan et al., 2003; Bending et al., 2004). In general, microbial biomass, enzyme activities, soil respiration, earthworm numbers and/or activity were observed to be higher in soils under organic practices than in those receiving synthetic inorganic fertilizers. Differences in microbial diversity between organically and conventionally managed soils were small (Shannon et al., 2002), although there is evidence for greater bacterial, Actinomycetes and fungal abundance and activity under organic management (Bulluck et al., 2002; Shannon et al., 2002). Mader et al. (2002) reported higher microbial biomass and enzyme activities in organics compared to conventional system of farming with and without farmyard 
manure. In contrast, some studies failed to find significant differences in microbial properties of soil between organic and conventional systems or suggested a negative impact of organic practices (Cook and Lee, 1995) while Aher et al. (2015) reported that soil organic carbon (11.3 $\left.\mathrm{g} \mathrm{kg}^{-1}\right)$ and enzyme activities in soil viz., dehydrogenase (DHA) $(98.20 \mu$ grams $\mathrm{TPF} / \mathrm{g}$ soil $/ 24 \mathrm{~h})$ and alkaline phosphatase $(178.2 \mu$ grams $\mathrm{p}$ nitro phenol/g soil/h) were significantly higher in the plots managed with organic practices with respect to conventional practices.

From the review, it was observed that organic farming showed a positive stimulating influence on the microbial populations in the soil (Rhizobium, Azotobacter and Azospirillium, phosphate solubilizing bacteria etc.). Overall, soil microbial populations were higher in soils under organic farming, indicating higher microbial activity under organic farming (Figure 3).

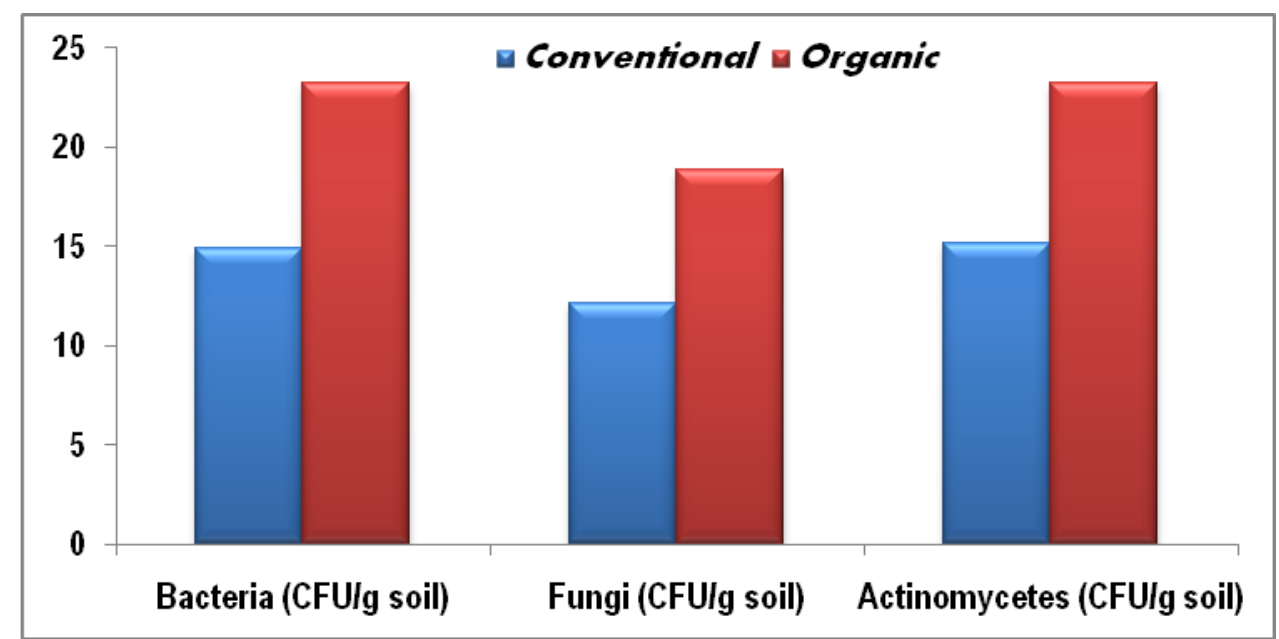

Figure 3. The bacteria, fungi and actinomycetes populations in soils under organic and conventional farming system (Sheoran, 2018)

\section{Conclusion}

The study concluded that conversion of land from conventional to organic farming found to have better soil quality in terms of physical, chemical and biological properties which is essential for enhancing soil productivity and other functions of soil in the given ecosystem. In the present agriculture scenario, organic farming may be adopted or promoted as an alternative to the conventional farming practices for sustainable use of natural resources, particularly, with respect to the impending global food safety coupled with climate change.

\section{REFERENCES}

[1] Abu-Zahra, T. R., Tahboub, A. B. (2008): Effect of organic matter sources on chemical properties of the soil and yield of strawberry under organic farming conditions. - World Applied Sciences Journal 5(3): 383-388.

[2] Aggelides, S. M., Londra, P. A. (2000): Effects of compost produced from town wastes and sewage sludge on the physical properties of a loamy and a clay soil. - Bioresourse Technology 71: 253-259. 
[3] Aher, S. B., Lakaria, B. L., Kaleshananda, S., Singh, A. B., Ramana, S., Ramesh, K., Thakur, J. K. (2015): Effect of organic farming practices on soil and performance of soybean (Glycine max) under semi-arid tropical conditions in Central India. - Journal of Applied and Natural Science 7(1): 67-71.

[4] Amaral, H. F., Ozinaldo, J., Sena, A., Regina, K., Schwan, E. F., Balota, E. L., Andrade, D. S. (2011): Soil chemical and microbial properties in vineyards under organic and conventional management in southern Brazil. - Brazilian Journal of Soil Science 35: 1517-1526.

[5] Andrist, R. Y., Edwards, A., Hillier, S., Oborn, I. (2007): Long-term K dynamics in organic and conventional mixed cropping systems as related to management and soil properties. - Agriculture, Ecosystems and Environment 122: 413-426.

[6] Araujo, A. S. F. (2009): Soil microbial activity in conventional and organic agricultural systems. - Sustainability 1: 268-276.

[7] Askegaard, M., Eriksen, J. (2007): Growth of legume and non-legume catch crops and residual-N effects in spring barley on coarse sand. - Journal of Plant Nutrition and Soil Science 170: 773-780.

[8] Babu, M. V. S., Ramakrishna, V. R., Parama, Prakash, S. S., Mohan, M., Reddy, V. S. (2014): Vertical distribution of soil total carbon and nitrogen stocks and other properties in profiles as influenced by organic and conventional farming systems under southern dry zone of Karnataka. - Progressive Agriculture 14(1): 10-16.

[9] Benbi, D. K., Sharma, S., Toor, A. S., Brar, K., Sodhi, G. P. S., Garg, A. K. (2016): Differences in soil organic carbon pools and biological activity between organic and conventionally managed rice-wheat fields. - Organic Agriculture 16: 168-182.

[10] Benbi, D. K., Toor, A. S., Kumar, S. (2012): Management of organic amendments in ricewheat cropping system determines the pool where carbon is sequestered. - Plant and Soil 360(1): 145-162.

[11] Bending, G. D., Turner, M. K., Rayns, F., Marx, M. C., Wood, M. (2004): Microbial and biochemical soil quality indicators and their potential for differentiating areas under contrasting agricultural management regimes. - Soil Biology \& Biochemistry 36: 17851792.

[12] Bhogal, A., Nicholson, F. A., Chambers, B. J. (2009): Organic carbon additions: Effects on soil bio-physical and physico-chemical properties. - European Journal of Soil Science 60: 276-286.

[13] Bobulska, L., Fazekasova, D., Angelovicova, L., Kotorova, D. (2015): Impact of ecological and conventional farming systems on chemical and biological soil quality indices in a cold mountain climate in Slovakia. - Biological Agriculture and Horticulture 26: 2-17.

[14] Brady, N. C., Weil, R. R. (2002). The nature and properties of soils. Upper Saddle River, N.J: Prentice Hall.

[15] Bulluck, L. R., Brosius, M., Evanylo, G. K., Ristaino, J. B. (2002): Organic and synthetic fertility amendments influence soil microbial, physical and chemical properties on organic and conventional farms. - Applied Soil Ecology 19: 147-160.

[16] Canqui, H. B., Charles, A., Francis, L., Tomie, D., Galusha (2013): Does organic farming accumulate carbon in deeper soil profiles in the long term? - Geoderma 288: 213-221.

[17] Carine, F., Capowiez, Y., Criquet, S. (2009): Enzyme activities in apple orchard agroecosystems: How are they affected by management strategy and soil properties? Soil Biology \& Biochemistry 41: 61-68.

[18] Chen, G., Wail, R. R. (2011): Root growth and yield of maize as affected by soil compaction and cover crops. - Soil \& Tillage Research 117: 17-27.

[19] Chin, F. S., Ho, Y. T., Khim, P. C., Jalloh, M. B., Wong, N. K. (2010): Organic versus conventional farming of Tea plantation. - Borneo Science 26: 19-26. 
[20] Chong, K. P., Ho, Y. T., Jalloh, M. B. (2008): Soil nitrogen phosphorus and tea leaf growth in organic and conventional farming of selected fields at Sabah Tea plantation slope. - Journal of Sustainable Development 1(3): 117-122.

[21] Chung, J. B. (2007): Comparison of Soil Physical Properties in Conventional and Organic Farming Apple Orchards. - Korean Journal of Environmental Agriculture 26(4): 279-285.

[22] Cook, H. F., Lee, H. C. (1995): Soil management in sustainable agriculture. Proceedings of the Third International Conference on Sustainable Agriculture, Wye College, University of London, 31 August to 4 September 1993.

[23] Crecchioa, C., Gelsominob, A., Ambrosolic, R., Minatic, J. L., Ruggiero, R. (2004): Functional and molecular responses of soil microbial communities under differing soil management practices. - Soil Biology \& Biochemistry 36: 1873-1883.

[24] Das, S., Kumar, P. B., Rajib, M. B. (2015): Infiltration characteristics of tea soil under organic and conventional farming systems in North-East India. - Journal of the Indian Society of Soil Science 63(4): 449-453.

[25] Degryze, S., Six, J., Paustian, K., Morris, S. J., Paul, E. A., Merckx, R. (2004): Soil organic carbon pool changes following land-use conversions. - Global Change Biology 10: $1120-1132$.

[26] Diepeningen, A. D., Vos, O. J., Korthals, G. W., Bruggen, A. H. C. (2006): Effects of organic versus conventional management on chemical and biological parameters in agricultural soils. - Applied Soil Ecology 31(2): 120-135.

[27] Edmeades, D. C. (2003): The long-term effects of manures and fertilizers on soil productivity and quality: a review. - Nutrient Cycling in Agroecosystems 66: 165-180.

[28] Esperschutz, J. (2007): Response of soil microbial biomass and community structures to conventional and organic farming systems under identical crop rotations. - FEMS Microbiology Ecology 61: 263-267.

[29] Fließbach, A., Oberholzer, H., Gunst, L., Mader, P. (2007): Soil organic matter and biological soil quality indicators after 21 years of organic and conventional farming. Agriculture, Ecosystems \& Environment 118(1-4): 273-284.

[30] Fortuna, A., Harwood, R. R., Paul, E. A. (2003): The effects of compost and crop rotations on carbon turnover and the particulate organic matter fraction. - Soil Science 168: 434-444.

[31] Franzluebbers, A. J., Stuedemann, J. A., Schomberg, H. H., Wilkinson, S. R. (2000): Soil organic C and N pools under long-term pasture management in the Southern Piedmont USA. - Soil Biology \& Biochemistry 32: 469-478.

[32] Fueki, N., Jerzy, L., Jan, K., Urszula, K., Artur, N. (2012): Difference in infiltration and macropore between organic and conventional soil management. - Soil Science and Plant Nutrition 58: 65-69.

[33] Gajda, A. M., Ewa, A. C., Dexter, A. R. (2016): Effects of long-term use of different farming systems on some physical, chemical and microbiological parameters of soil quality. - International Agrophysics 30: 165-172.

[34] Ge, T., Nie, S., Wu, J., Shen, J., Xiao, H., Tong, C., Huang, D., Hong, Y., Iwasaki, K. (2011): Chemical properties, microbial biomass, and activity differ between soils of organic and conventional horticultural systems under greenhouse and open field management: A case study. - Journal of Soils and Sediments 11: 25-36.

[35] Girvan, M. S., Bullimore, J., Pretty, J. N., Osborn, A. M., Ball, A. S. (2003): Soil type is the primary determinant of the composition of the total and active bacterial communities in arable soils. - Applied \& Environmental Microbiology 69: 1800-1809.

[36] Glover, J. D., Reganold, J. P., Andrews, P. K. (2000): Systematic method for rating soil quality of conventional, organic, and integrated apple orchards in Washington State. Agriculture, Ecosystems \& Environment 80: 29-45.

[37] Gomiero, T., Pimentel, D., Paoletti, M. G. (2011): environmental impact of different agricultural management practices: conventional vs. organic agriculture. - Critical Reviews in Plant Sciences 30(1-2): 95-124. 
[38] Hansen, B. Alroe, H. F., Kristensen, E. S. (2001): Approaches to assess the environmental impacts of organic farming with particular regard to Denmark. Agriculture, Ecosystem and Environment 83(1-2): 11-26.

[39] Hati, K., Bandyoopadhay, K. (2011): Fertilizers (Mineral, Organic) Effect on Soil Physical Properties. - In: Gliński, J., Horabik, J., Lipiec, J. (eds.) Encyclopedia of Agrophysics. Springer, Dordrecht-Heidelberg-London-New York.

[40] Herencia, J. F., Ruiz-porras, J. C., Melero, S., Garciagalavis, P. A., Morillo, E., Maqueda, C. (2007): Comparison between organic and mineral fertilization for soil fertility levels, crop macronutrient concentrations, and yield. - Agronomy Journal 99: 973-983.

[41] Ikemura, Y., Shukla, M. K., Tahboub, M., Leinauer, B. (2008): Some physical and chemical properties of soil in organic and conventional farms for a semi-arid ecosystem of New Mexico. - Journal of Sustainable Agriculture 31: 149-170.

[42] Jadhav, A. B., Kadlag, A. D., Amrutsagar, V. M. (2016): Soil enzyme activities, organic carbon and microbial population as influenced by integrated nitrogen management for Banana. - Journal of the Indian Society of Soil Science 64(1): 98-107.

[43] Jenkins, L. J., Sakrabani, R., Pearce, B., Whitmore, A. P., Godwin, R. J. (2011): A comparison of soil and water properties in organic and conventional farming systems in England. - Soil Use and Management 27: 133-142.

[44] Krol, A., Lipiec, J., Turski, M., Kuoe, J. (2013): Effects of organic and conventional management on physical properties of soil aggregates. - International Agrophysics 27: $15-21$.

[45] Kumar, V. (2012): Comparison of twelve organic and conventional farming systems: A life cycle greenhouse gas emissions perspective. - Journal of Sustainable Agriculture 36: 620-649.

[46] Lampkin, N. H., Measures, M., Padel, S. (2011): Organic Farm Management Handbook. - 9th ed. Organic Research Centre, Newbury.

[47] Lee, Y. H., Lee, S. M., Sung, J. K., Kim, Y. H., Choi, D. H., Ryu, G. H. (2006): The effects of applied organic materials for improving soil physico-chemical properties in paddy fields. $-18^{\text {th }}$ World Congress of Soil Sci. Philadelphia, PA, USA.

[48] Leifeld, J., Fuhrer, J. (2010): Organic farming and soil carbon sequestration: what do we really know about the benefits? - Ambio 39: 585-599.

[49] Leifeld, J., Reiser, R., Oberholzer, H. R. (2009): Consequences of conventional versus organic farming on soil carbon: results from a 27 -year field experiment. - Agronomy Journal 101(5): 204-1218.

[50] Levick, M. (1992): A comparison of some aspects of two orchard plot management systems. - B. Holt (Tech) thesis. Dept. of Soil Science, Mavvey Univ., Palmerston North, New Zealand.

[51] Liebig, M. A., Doran, J. W. (1999): Impact of organic production practices on soil quality indicators. - Journal of Environmental Quality 28: 1601-1609.

[52] Liu, B., Tu, C., Hua, S., Gumpertz, M., Ristaino, J. B. (2007): Effect of organic, sustainable, and conventional management strategies in grower fields on soil physical, chemical, and biological factors and the incidence of Southern blight. - Applied Soil Ecology 37: 202-214.

[53] Lopes, A. R., Faria, C., Prieto-Fernández, A., Trasar, C. C., Manaia, C. M., Nunes, O. C. (2011): Comparative study of the microbial diversity of bulk paddy soil of two rice fields subjected to organic and conventional farming. - Soil Biology \& Biochemistry 43: 115125 .

[54] Lotter, D. W. (2003): Organic agriculture. - Journal of Sustainable Agriculture 21: 59128.

[55] Mader, P., Fließbach, A., Dubois, D., Gunst, L., Fried, P., Niggli, U. (2002): Soil fertility and biodiversity in organic farming. - Science 296: 1694-1697. 
[56] Maharjan, M., Sanaullah, M., Bahar, S., Razavi, Kuzyakov, Y. (2017): Effect of land use and management practices on microbial biomass and enzyme activities in subtropical topand sub-soils. - Applied Soil Ecology 113: 22-28.

[57] Malhi, S. S., Nyborg, M., Solberg, E. D., McConkey, B., Dyck, M., Puurveen, D. (2011): Long-term straw management and $\mathrm{N}$ fertilizer rate effects on quantity and quality of organic $\mathrm{C}$ and $\mathrm{N}$ and some chemical properties in two contrasting soils in western Canada. - Biology and Fertility of Soils 47: 785-800.

[58] Malik, S. S., Ramesh, C., Chauhan, J. S., Kapoor, T., Raashee, A., Sharma, N. (2014): Influence of organic and synthetic fertilizers on soil physical properties. - International Journal of Current Microbiology and Applied Sciences 3(8): 802-810.

[59] Marriott, E. E., Wander, M. M. (2006): Total and labile soil organic matter in organic and conventional farming systems. - Soil Science Society of America Journal 70: 950-959.

[60] Melero, S. (2006): Chemical and biochemical properties in a silty loam soil under conventional and organic management. - Soil \& Tillage Research 90: 162-170.

[61] Mendoza, G. O., Shukla, M. K., John, G., Mexal, Vanleeuwen, D. M., Ikemura, Y. (2011): Assessment of properties of a Harkey soil under organic and conventional farming systems. - Communications in Soil Science and Plant Analysis 42: 1791-1808.

[62] Moeskops, M. B., Sukristiyonubowo, B., Buchana, D., Sleutel, S., Herawaty, L., Husenb, E., Saraswati, R., Setyorini, D., De, N. S. (2010): Soil microbial communities and activities under intensive organic and conventional vegetable farming in West Java, Indonesia. - Applied Soil Ecology 45: 112-120.

[63] Mohamad, R. S., Vincenzo, A. C., Verrastro, A., Bitar, A. L., Rocco, R. B., Michele, M. B., Chami, Z. A. (2016): Effect of different agricultural practices on carbon emission and carbon stock in organic and conventional olive systems. - Soil Research 10: 1071-80.

[64] Monokrousos, N., Papatheodorou, E. M., Diamantopoulos, J. D., Stamou, G. P. (2006): Soil quality variables in organically and conventionally cultivated field sites. - Soil Biology and Biochemistry 38: 1282-1289.

[65] Montgomery, D. R. (2007a): Soil erosion and agricultural sustainability. - Proceedings of the National Academy of Sciences (PNAS) 104: 13268-13272.

[66] Ochiai, N., Powelson, M., Crowe, F., Dick, R. (2008): Green manure effects on soil quality in relation to suppression of Verticillium wilt of potatoes. - Soil Biology and Biochemistry 44: 1013-1023.

[67] Okur, N., Ahmed, A., Muzaffer, C., Selçuk, G. N., Huseyin, H. K. (2009): Microbial biomass and enzyme activity in vineyard soils under organic and conventional farming systems. - Turkish Journal of Agriculture and Forestry 33: 413-423.

[68] Otero, V., Barreal, M. E., Martínez, N. L., Gallego, P. P. (2010): Nutritional status of kiwifruit in organic and conventional farming systems. - Proceedings $\mathrm{VI}^{\mathrm{th}}$ IS on Mineral Nutrition of Fruit Crops, pp. 155-160.

[69] Pang, X. P., Letey, J. (2000): Organic farming: Challenge of timing nitrogen availability to crop nitrogen requirements. - Soil Science Society of America Journal 64: 247-253.

[70] Papadopoulos, A., Bird, N. R., Whitmore, A. P., Mooney, S. J. (2006): The effects of organic farming on the soil physical environment. - Aspects of Applied Biology 79: 263267.

[71] Pelosi, C., Bertrand, M., Thenard, J., Mougin, C. (2015): Earthworms in a 15 year agricultural trial. - Applied Soil Ecology 88: 1-8.

[72] Petersen, S. O., Debosz, K., Schonning, P., Christensen, B. T., Elmholt, S. (1997): Phospholipid fatty acid profiles and $\mathrm{C}$ availability in wet-stable macro-aggregates from conventionally and organically farmed soils. - Geoderma 78: 181-196.

[73] Pimentel, D., Edwards, C. A. (1982): Pesticide and ecosystem. - BioScience 32: 595-600.

[74] Poudel, D. D., Ferris, H., Klonsky, H., Horwath, W. R., Scow, K. M., Van Brugen, A. H. C., Lanini, W. T., Mitchell, J. P., Temple, S. R. (2001): The sustainable agriculture farming system project in California's Sacramento Valley. - Outlook on Agriculture 30: $159-160$. 
[75] Poudel, D. D., Horwath, W. R., Lanini, W. T., Temple, S. R., Bruggen, A. H. C. (2002): Comparison of soil $\mathrm{N}$ availability and leaching potential, crop yields and weeds in organic, low-input and conventional farming systems in northern California. Agriculture, Ecosystems and Environment 90: 125-137.

[76] Pulleman, M. M., Six, J., Breemen, N., Jongmans, A. G. (2004): Soil organic matter distribution and microaggregate characteristics as affected by agricultural management and earthworm activity. - European Journal of Soil Science 9: 759-772.

[77] Quist, K., Strock, J. S., Mulla, D. J. (2006): Influence of alternative and conventional management practices on soil physical and hydraulic properties. - Vadose Zone Journal 5: 356-364.

[78] Reganold, J. P., Andrews, P. K., Reeve, J. R., Boogs, C. L., Schadt, C. W., Alldredge, R., Ross, C. F., Davies, N. M., Zhou, J. (2010): Fruit and soil quality of organic and conventional strawberry agroecosystem. - Plos One 5(9): 123-146.

[79] Romanya, J., Rovira, P. (2009): Organic and inorganic P reserves in rain-fed and irrigated calcareous soils under long-term organic and conventional agriculture. - Geoderma 151: 378-386.

[80] Rothamsted Research (2005): Annual Report 2004-2005 World Class Science for Sustainable Land Management. - The Laws Trust, Rothamsted.

[81] Schjonning, P., Elmholt, S., Munkholm, L. J., Debosz, K. (2002): Soil quality aspects of humid sandy loams as influenced by organic and conventional long-term management. Agriculture, Ecosystems \& Environment 88: 195-214.

[82] Schnug, E., Haneklaus, S. (2002): Agricultural production techniques and infiltration significance of organic farming for preventive flood protection. - Land Bauforsch Volkenrode 52: 197-203.

[83] Schnug, E., Rogasik, J., Panten, K., Paulsen, H. M., Haneklaus, S. (2004): Oekologischer Landbau erhoeht die Versickerungsleistung von Boeden - ein unverzichtbarer Beitrag zum vorbeugenden Hochwasserschutz. - Oekologie \& Landbau 32(132): 53-55.

[84] Shannon, D., Sen, A. M., Johnson, D. B. (2002): A comparative study of the microbiology of soils managed under organic and conventional regimes. - Soil Use \& Management 18: 274-283.

[85] Sheoran, H. S. (2018). Impact of organic and conventional farming practices on soil quality. Ph.D. Thesis. - Department of Soil Science, CCS Haryana Agriculural University, Hisar (India).

[86] Shepherd, M. A., Harrison, R., Webb, J. (2002): Managing soil organic matterimplications for soil structure on organic farms. - Soil Use \& Management 18: 284-292.

[87] Shepherd, M., Pearce, B., Cormack, B., Phillipps, L., Cuttle, S., Bhogal, A., Costagin, P., Unwin, R. (2003): An assessment of the environmental impacts of organic farming. http://www.defra.gov.uk/science/ (accessed on 01/03/2005).

[88] Shrestha, G. (2014): Soil properties and soil management practices in commercial organic and conventional vegetable farms in Kathmandu Valley. - Nepal Journal of Science and Technology 15(1): 13-22.

[89] Shukla, M. K., Lal, R., Owens, L. B., Unkefer, P. (2003): Land use and management impacts on structure and infiltration characteristics of soils in the north Appalachian region of Ohio. - Soil Science 168: 167-177.

[90] Siegrist, S. S., Pfiffner, D., Mader, P. (1998): Does organic agriculture reduce soil erodibility? The results of a long-term field trial study on loess in Switzerland. Agriculture, Ecosystems \& Environment 69: 253-264.

[91] Sihi, D., Dari, B., Dinesh, K., Sharma, H. P., Nain, L., Sharma, O. P. (2017): Evaluation of soil health in organic vs. conventional farming of basmati rice in North India. - Journal of Plant Nutrition and Soil Science 2: 1-18.

[92] Sihi, D., Sharma, D. K., Pathak, H., Singh, Y. V., Sharma, O. P., Nain, N., Chaudhary, A., Dari, B. (2012): Effect of organic farming on productivity and quality of basmati rice. - Journal of Rice Research 49: 24-29. 
[93] Smitha, G. R., Umesha, K., Sreeramu, B. S. (2015): Soil and plant nutrient status as influenced by organic farming in Long pepper. - Journal of Medicinal and Aromatic Plants 6(1): 21-28.

[94] Stark, C. H. (2008): Are soil biological properties and microbial community structure altered by organic farm management? - Proceedings of IFOAM Organic World Congress 16, Modena, Italy, pp. 121-124.

[95] Sudhakaran, M., Ramamoorthy, D., Kumar, R. S. (2013): Impacts of conventional, sustainable and organic farming system on soil microbial population and soil biochemical properties, Puducherry, India. - International Journal of Environmental Sciences 4: 2841.

[96] Suja, G., Byju, G., Jyothi, A. N., Veena, S. S., Sreekumar, J. (2017): Yield, quality and soil health under organic vs. conventional farming in Taro. - Scientia Horticulturae 218: 334-343.

[97] Sunita (2015): Effect of organic farming on quality of soil under rice cultivation. Journal of Agroecology and Natural Resource Management 2(5): 391-393.

[98] Thuries, L., Feller, C., Herrmann, P., Remy, J. (2001): Kinetics of added organic matter decomposition in a Mediterranean sandy soil. - Soil Biology \& Biochemistry 33(7-8): 997-1010.

[99] Uddin, M. N., Siddiqy, M. A., Hossain, A. M., Islam, F., Halim, G. M. A., Bari, M. L. (2016): Impact of organic and conventional practices on, soil health and crop yield under tropical and subtropical environment of Bangladesh. - International Journal of Environment \& Agriculture Research 2(12): 89-100.

[100] Velmourougane, K. (2016): Impact of organic and conventional systems of coffee farming on soil properties and culturable microbial diversity. - Scientifica. http://dx.doi.org/10.1155/2016/3604026.

[101] Wander, M. M., Traina, S. J. (1996): Organic matter fractions from organic and conventionally managed soils: carbon and nitrogen distribution. - Soil Science Society of America Journal 60: 1081-1087.

[102] Willer, H., Lernoud, J. (2013): The World of Organic Agriculture: The Results of the Latest Survey on Organic Agriculture Worldwide. - Bio-Fach Congress, Nuremberg, Germany.

[103] Williams, D. M., Canqui, H. B., Charles, A. F., Galusha, T. D. (2017): Organic farming and soil physical properties: an assessment after 40 years. - Journal of Agronomy 109: 600-609.

[104] Wortman, S. E., Galusha, T. D., Mason, S. C., Francis, C. A. (2011): Soil fertility and crop yields in long-term organic and conventional cropping systems in eastern Nebraska. - Renewable Agriculture and Food Systems 27: 200-216.

[105] Wu, T., Chellemi, D., Graham, J., Martin, K., Rosskopf, E. (2008): Comparison of soil bacterial communities under diverse agricultural land management and crop production practices. - Microbial Ecology 55: 293-310.

[106] Zeiger, M., Fohrer, N. (2009): Impact of organic farming systems on runoff formation processes - A long-term sequential rainfall experiment. - Soil \& Tillage Research 102: 45-54.

[107] Zhao, J., Chen, S., Hu, R., Li, Y. (2017): Aggregate stability and size distribution of red soils under different land uses integrally regulated by soil organic matter, and iron and aluminum oxides. - Soil \& Tillage Research 167: 73-79. 